\title{
Is Community Forestry Supporting for Minimizing the Income Inequality of Different Social Strata of Users' Households: A case from Gorkha, Nepal
}

\author{
Mohan Raj Kafle ${ }^{1} \&$ Chiranjibi Pd. Upadhyaya ${ }^{2}$ \\ Corresponding Author: Mohan Raj Kafle \\ Email:mkafle@gmail.com
}

\begin{abstract}
:
This research paper describes the share of community forest income to the total income of users' households and its role in minimizing the inequality among different socio-economic group of users. Community forests support $12.3 \%$ of total household income to poor, $4.06 \%$ to middle and only $2.78 \%$ to rich class households. As there is huge difference in household income between three classes, the absolute income of $C F$ to rich class households is largest though it seems greater to the poor in percentage income terms. Share of household input in terms of annual household income is highest (10.6\%) for poor class households and lowest (2.4\%) for rich class. CF income has more equalizing effect in the household income of poor class households.
\end{abstract}

Key Words : Community forest, Household, Income, Inequality, Class

\section{Introduction}

The implementation of community forestry through forest user groups in Nepal has not yet been evaluated widely. A quantitative assessment of product flows and values to different households is an important aid in designing effective project and policy interventions (Richards et al., 1999). In particular, given the government's current emphasis on poverty reduction as a critical component of natural resource management, the benefits of community forestry can be understood considering their utility to households that have different wealth rankings (Kanel and Varughese, 2000). It is important to understand the connection between forest resources and the livelihood of the rural households (Barham et al., 1999; Kramer et al., 1995 and Ghimire, 2007). The importance of community forest products in rural livelihoods is highlighted in several studies (Bartlett and Malla, 1992; Varughese and Ostrom, 2001; Smith et al., 2003; Chhetri, 2005 and Ghimire, 2007). Despite this, limited information is available on the role of community forestry in minimizing the income inequality among different socio-economic strata of the users' household. Forest products being the economic goods are important sources of income that have direct

${ }^{1}$ Assistant Forest Officer, District Forest Office, Nawalparasi

2 Professors and Dean Institute of Forestry, Pokhara, Nepal 
influence on poverty alleviation of rural communities. Thus, the current issue is what the economic value of forest products is, and its contribution in poor's households in CFUG. Similarly, the analysis of the contribution of CF in household level income will produce insight regarding the effectiveness of CF programme for household level. Household level income inequalities also raise concern over the use of forest resources (Olsen and Helles, 1997; Chakraborty, 2001). Estimating the economic contribution of the forest resources and the inequality of the derived income are the key steps towards understanding the role of community forestry in rural peoples' day to day life.

\section{Materials and methods}

The study was carried out in in Gorkha district in the middle hills. The household was taken as the unit of sampling. From the 32 households of wealth-class I, 30 of the class II and 30 from class III (total 92 households) were selected purposively using simple random sampling method. Primary information were collected using semi-structured questionnaires, checklists and matrix through household survey and interviews, focus group discussions, informal discussions and direct field observation. Secondary information and records were collected from different published and unpublished literatures from different sources. The quantitative data were analyzed using frequency distribution, mean, standard deviation, ANOVA, Least significant Difference/ LSD and Lorenz curve \& Gini coefficients.

\section{Findings}

\section{Share of Community Forest Income in Total Household Income}

Non-farm source of the income (mostly income from in-country and foreign services) is the major source of the sampled household which comprise of $65.57 \%$ of the total household income. Agriculture is the second largest income source (16.9\%) and livestock supports $10.9 \%$. Community forest contributes only $4.22 \%$ of the household income. Poor class household is receiving $12.3 \%$, middle class $4.06 \%$ and the rich class households are receiving $2.78 \%$ of their total household income from Community forest.

\section{Disparity in Income of Households and Effect of CF Income}

There is a clear gap in the total household income of three categories of households. The mean annual total household income of poor households is NRs 43338 whereas the middle household has NRs 103854 and the rich household is NRs 219650 having minimum income of NRs 15785 and the maximum income NRs 381090. It shows the great disparity in the mean household income of poor and the rich household category of income.

The income inequality of the household is shown by drawing the Lorenz curve and calculating the Gini coefficient. The departure of the line below the line of equality (straight line) in the Lorenz curve shows the inequality (diagonal line) to the household income. Farther the line from the line of equality, greater is the inequality it represents. Figures 1 
to 6 represent the Lorenz curve for household income of Rich, Middle and Poor categories for both the cases of inclusion and exclusion of CF income and total forest income (CF and Private Forest). The inner curve (continuous line) towards the line of equality is the Lorenz curve that includes the income of Community Forest and the outer curve (dotted line) is the Lorenz curve that excludes the income from Community Forest (in figure 1, $3 \& 5$ ). Likewise in figure 2, $4 \& 6$, the inner Lorenz curve towards the line of equality (diagonal line) shows the household income including the total forest products' income and the outer curve (dotted line) shows the household income excluding the forest income(income from communityforest plus private forest).

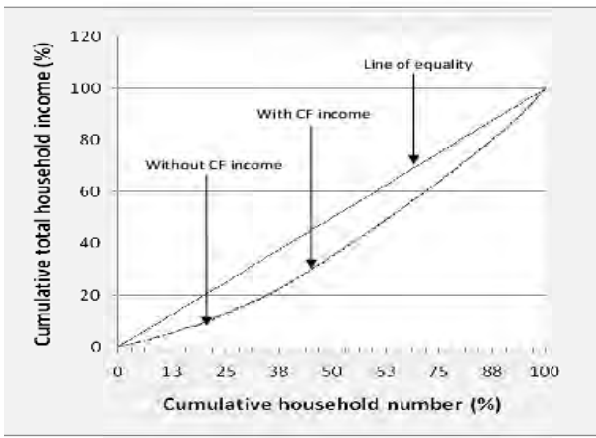

Figure 1: Lorenz Curve of total household income (With and without CF income) for Rich class of users

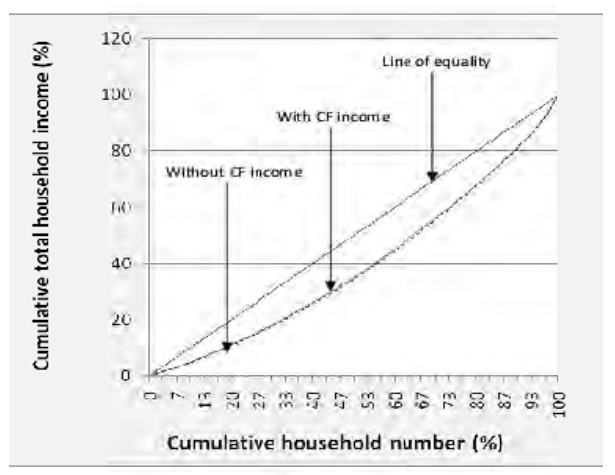

Figure 3: Lorenz Curve of total household income (With and without CF income) for Middle class of users

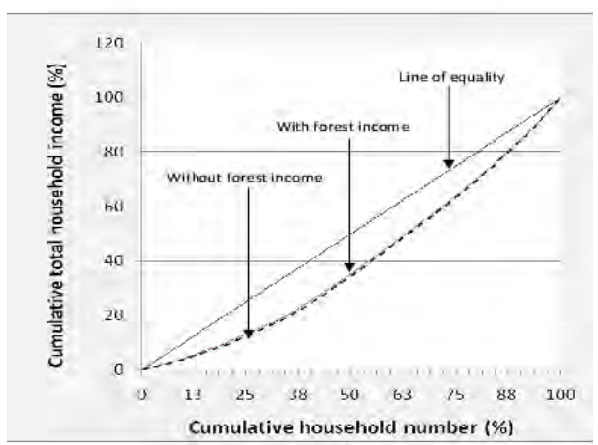

Figure 2: Lorenz Curve of total household income (With and without total income from forest products) for Rich class of users

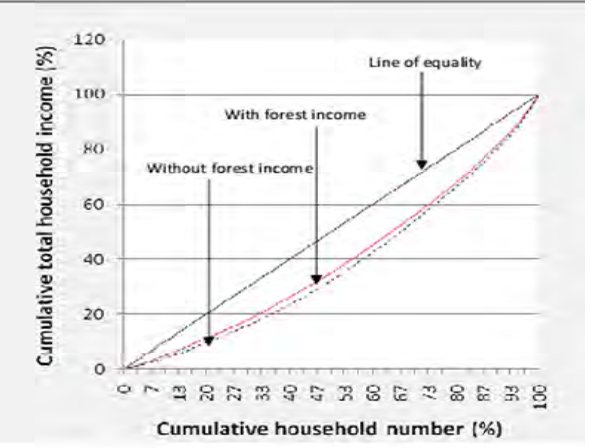

Figure 4: Lorenz Curve of total household income (With and without total income from forest products) for Middle class of users 


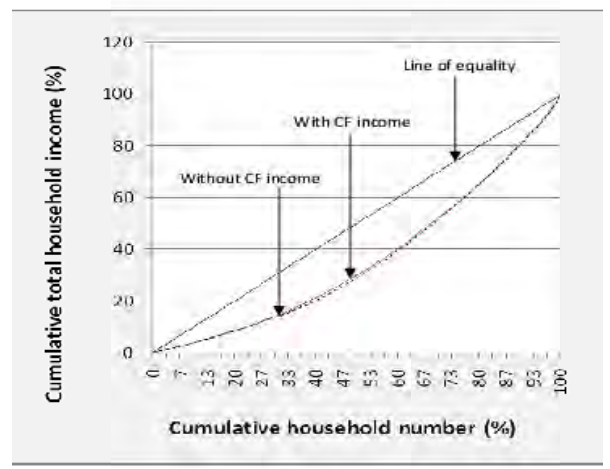

Figure 5: Lorenz Curve of total household income (With and without CF income) for Poor class of users

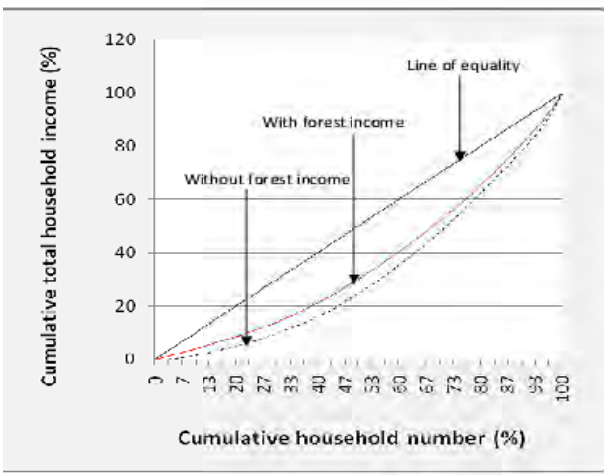

Figure 6: Lorenz Curve of total household income (With and without total income from forest products) for Poor class of users

Figure 1, 3 \& 5 show that the Lorenz curve of total household income without CF income is deviated far than the Lorenz curve of household income with CF income. The deviation of the curve of total household income is further increase when the total forest income (CF income plus PF income) is excluded from the total household income of the households. There is a very negligible outward shift in the Lorenz curve when the CF income is excluded from the household income. The shift is slightly greater in the poor household than in the rich and middle class households. But the outward shift in the Lorenz curve is remarkable in middle and poor class households when the total forest income is excluded from the household income. It is still negligible in the case of rich class households. The movement is more in case of poor class households than in the middle class households. So, it is obvious that Private forest products has remarkable share in the total household income of the Poor and Middle class households and very low in the case of rich class household.

It is found that the income from the use of forest products has helped to reduce the income inequality in all categories of users, having the high contribution to the poor and middle class households (when both the community and private forest use is considered). 
Table 1: Gini coefficient of household categories excluding CF income and total forest income

\begin{tabular}{|l|l|l|l|}
\hline $\begin{array}{c}\text { Household } \\
\text { category }\end{array}$ & Total HH income & $\begin{array}{c}\text { HH income } \\
\text { without CF income }\end{array}$ & $\begin{array}{c}\text { HH income } \\
\text { without total forest } \\
\text { income }\end{array}$ \\
\hline Rich & 0.21 & 0.22 & 0.23 \\
\hline Middle & 0.22 & 0.23 & 0.26 \\
\hline Poor & 0.28 & 0.29 & 0.36 \\
\hline Total & $\mathbf{0 . 4 0}$ & $\mathbf{0 . 4 2}$ & $\mathbf{0 . 4 5}$ \\
\hline
\end{tabular}

The Gini coefficient for total household income in this study is found 0.40 which is greater than the national Gini coefficient of 0.35 (Giovanna) and the similar study by Chhetri (2005) which is 0.38 in Kaski but greater than the findings of the study by Ghimire (2007) in Kavrepalanchok District of Nepal which is 0.48 . The Gini coefficient for household income of rich class household is 0.21 , middle class is 0.22 and the poor class is 0.28 . When total forest income is excluded from the total household income the Gini increased from 0.40 to 0.45 in the study area. But when only the CF income is excluded, it increased from 0.40 to 0.42 only. The departure of Lorenz curves and the variation in values of Gini coefficient indicate that income from the forest products collected from community and private forests helps in minimizing the income inequalities between the user households though with small share.

Income percentage of the rich household has increased (from $61.6 \%$ to $62.3 \%$ ) when the community forest income is excluded from the total household income. The income ratio further increased (to 64.3\%) when the total forest income is excluded from the household income. In the middle class households, the income remained more or less same when the community forest income is excluded (only shifted from $27.2 \%$ to $27.3 \%$ ) but decreased from $27.2 \%$ to $26.6 \%$ when the total forest income is excluded from the household income. The case is different for the poor class households. When the CF income is excluded from the total household income, the percentage household income decreased from $11.4 \%$ to $10.4 \%$. The percentage income further decreased to $9.1 \%$ when the total forest income is excluded from the total household income of poor class households.

The above mentioned result clarify that the income from the use of forest products from community forest and other forest has support to equalize the household income of the poor class household. It seems that CF income has unremarkable effect but total forest income has equalizing effect for the middle class household. But income from the use of forest products from CF and other forest sources has not contributed to the rich class household to equalize the household income in the study area. These findings are also supported by the findings of several other studies (Byron and Arnold, 1999; Chhetri, 2005; Ghimire, 2007) which stated that the $\mathrm{CF}$ income has equalizing effect in the household income of the CF users, especially the poor class households. 


\section{Conclusion}

Community forest contributes $4.22 \%$ of the users' total household income. Rich class households are getting more net and gross income from the use of CF products than poor and middle class $\mathrm{HHs}$ in absolute terms, but the difference in the income between these three classes is insignificant. In contrast, the percentage share of CF income in terms of total $\mathrm{HH}$ income becomes high for poor class $\mathrm{HH}$ s as their total $\mathrm{HH}$ income is very low compared to richer class households. In terms of absolute contribution rather than percentage share to the household income, community forests contribute more to the well-off households compared to the poor households. Although the actual amount of income to the poor households is low than richer class households, it has significant impact to support poor households. The income from the use of forest products has helped to reduce the income inequality in all three categories of users, having the higher contribution to the poor and middle class households when both $\mathrm{CF}$ and Private forest products are considered. But income from CF only has a very low or negligible effect to equalize the income inequality gap. In fact, the equalizing effect of CF income and total forest income is insignificant.

\section{References}

Bartlett, A.G. and Malla, Y.B. 1992. Local Forest Management and Forest Policy in Nepal. Journal of World Forest Resource Management 6: 99-116.

Byron, N. and Arnold, M. 1999. What futures for the people of tropical forest? World Development, 27(5): 789- 805.

Chhetri, B.B.K. 2005. Community Forestry Programmes in the Hills of Nepal: Determinants of Users Participation and Household Dependency. M. Sc. Thesis, Norwegian University of Life Science (UMB).

Ghimire, G.P. 2007. Contribution ofCommunity Forestry in Community Development and Household Income: A Case Study from Kavrepalanchowk District, Nepal.M. Sc. Thesis, Institute of Forestry, Pokhara, Nepal.

Jayaraman, K. 2000. A statistical Manual for Forestry Research. FORSPA Publication No. 25/2000. Forestry Research Support Programme for Asia and the Pacific, FAO, Bangkok.

Kanel, K. and Varughese, G. 2000. Quantifying the Benefits of Community Forestry: Towards Development of a Participatory Methodology of Economic Valuation. Paper prepared for discussion at the $8^{\text {th }}$ Biennial meeting of the International Association for study of Common Property (IASCP) at Indiana University, 30 May - 4 June 2000 Indiana, USA.

Olsen, C.S. and Helles, F. 1997. Making the poorest poorer: policies, laws and trade in medicinal plants in Nepal. Journal of World Forest Resource Management 8: 137158. 
Smith, D.M., Chhetri, B.B.K. and Regmi, B. 2003. Meeting the needs of Nepal's poor. Creating local criteria and indicators of community forestry. Journal of Forestry 101(5): 24-30.

Varughese, G. and Ostrom, E. 2001. The Contested Role of Heterogeneity in Collective Action: Some Evidence from Community Forestry in Nepal. World Development 29(5), 747-765. 